\title{
Cytological Studies in Cluster bean by the application of physical and chemical mutagens (Cyamopsis tetragonoloba L.)
}

\author{
L. Mullainathan, T. Aruldoss ${ }^{*}$, S. Velu \\ Department of Botany, Annamalai University, Annamalai Nagar 608 002, Tamil Nadu, India \\ *E-mail address: arulkuttykly@gmail.com
}

\begin{abstract}
The miotic and meotic behaviour is considered to be one of the most dependable indices to estimate the potency of mutagen cytological aberrations in plants serve as an excellent monitoring system for the determination of mutagens that may cause a genetic hazard in the present study cluster bean contains 7 bivalents $(24=14)$ for the present investigation the plant exposed to dolf concentration of 60,80 , and $100 \mathrm{kr}$ gamma rays and $0.4,0.6$ and $0.8 \% \mathrm{Mm}$ ( EMS ) the present study reveals various chromosomal aberration includes stickiness precocisus movement, single and anaphasis bridge laggards and synchronized movement of chromosomes at anaphase.
\end{abstract}

Keywords: chemical mutagens; Cyamopsis tetragonoloba; bean

\section{INTRODUCTION}

Legumes are considered as the major source of dietary protein and amino acid for man and farm animals (Baudoin and Maquet, 1991). A major part of the human diet all over the world consists of cereals and legumes (Mandal and Mandal, 2000). According to estimation of FAO, $70 \%$ of human food comprises cereals and legumes and the remaining $30 \%$ comes from animals (FAO, 1970). Pulses also play an important role as sustainable agricultural by maintaining and restoring soil fertility through biological nitrogen fixation (Asthana, 1998). In India, pulses are generally grown on marginal or sub-marginal lands which have very poor fertility status (Punjari and Sheelvantar, 2001). It is a cheap source of dietary protein (24\%), which also contains $60 \%$ carbohydrate, $2 \%$ fat and rich amount of vitamins and phosphorous (Venkatesan, 1997).

Cluster bean (Cyamopsis tetragonoloba (L.) Taub) is belongs to the family Fabaceae. It's an annual summer legume crop of India and Pakistan. It is grown in over area of about 242.6 thousand tons annually with an average yield $909.7 \mathrm{~kg} /$ ha (Anonymous, 2003). It is also an important short duration multi-purpose legume and cultivated throughout the tropics and sub tropics areas. The green pods are used as vegetable and fodder. 


\section{MATERIAL AND METHODS}

In the present investigation, one of the genotype of cluster bean variety namely "Pusa Navabahar" was collected from Millet Breeding Station, Tamil Nadu Agricultural University, Coimbatore, Tamil Nadu. The present research work was carried out in Cytology laboratory and Botanical Garden of the Department of Botany, Annamalai University, Annamalai Nagar, Tamil Nadu.

This study was through induced mutation by physical and chemical mutagens namely, gamma rays, Ethyl Methane Sulphonate (EMS), Sodium Azide (SA) and Colchicine (COH) and their effects on quantitative and qualitative traits like early maturing, high yielding and improved protein content of cluster bean variety Pusa Navabahar by means of extending the genetic variability with cytological constituents.

For mitotic studies young and healthy root tips were collected between 8.45 to $9.30 \mathrm{am}$ and thoroughly washed in water. They were pre treated in $0.002 \mathrm{M}$ hydroxyl quinoline at 4 ${ }^{\circ} \mathrm{C}$ for $3 \mathrm{hrs}$. Then, the root tips were thoroughly washed in water and fixed in 1:3 acetic alcohol for $3 \mathrm{hrs}$ overnight. Again the root tips were washed in distilled water. Then the root tip squashes were prepared following iron alum haematoxylin squashes technique (Marimuthu and Subramaniam, 1960). Squash were made with one or two root tips per slide and temporarily sealed. The iron alum haematoxylin staining method was found to be more satisfactory in counting number and studying the morphological features of the chromosomes.

\section{RESULTS AND DISCUSSION}

In control plants, Gamma radiation treated plants, EMS and sodium azide treated plants, only diploid cells with $2 \mathrm{n}=14$ chromosomes have been observed. This suggests that may be point mutations or gene mutations taken place.

In control, the root tip cells show $2 \mathrm{n}=14$ chromosomes and no mitotic aberrations have been observed. But, in gamma radiation treated plants along with $2 \mathrm{n}=14$ chromosomes irregular pairing up of chromosomes and precious movement of them have been noted. In EMS treated plants along with cells having $2 \mathrm{n}=14$ chromosomes cells with irregular arrangements of chromosomes, broken metaphases and anaphase bridges have been also observed. In sodium azide treated plants along with cells having $2 \mathrm{n}=14$ chromosomes, rare occurrences of anaphasic bridges and laggards have been noted. In colchicine treated plants occurrence of $4 n=28$ chromosomes (polyploids) in more number of cells have been observed. Besides, mitotic aberrations like broken metaphase, irregular anaphase, anaphasic laggards and anaphasic bridges occur more frequently. Such aberrations are not observed in control plants (Plates I and II).

In colchicine treated plants, along with diploid cells, polyploid cells also have been observed, mostly tetraploid cells and rarely triploid (3n), haploid (n) and pentaploid cells $(5 n)$ in the root tips.

The details about the percentage occurrence of mitotic aberrations in the root tip cells particularly broken metaphases, anaphasic laggards and anaphasic bridges in various control gamma radiation treated plants $(60,80$ and $100 \mathrm{kR})$, EMS treated plants $(0.4,0.6$ and $0.8 \%)$, sodium azide treated plants $(0.02,0.03$ and $0.04 \%)$ and colchicine treated plants $(0.12,0.14$ and $0.16 \%$ ) are furnished in (Table 1.). 
Plate I

MITOSIS

Microphotographs X 1250
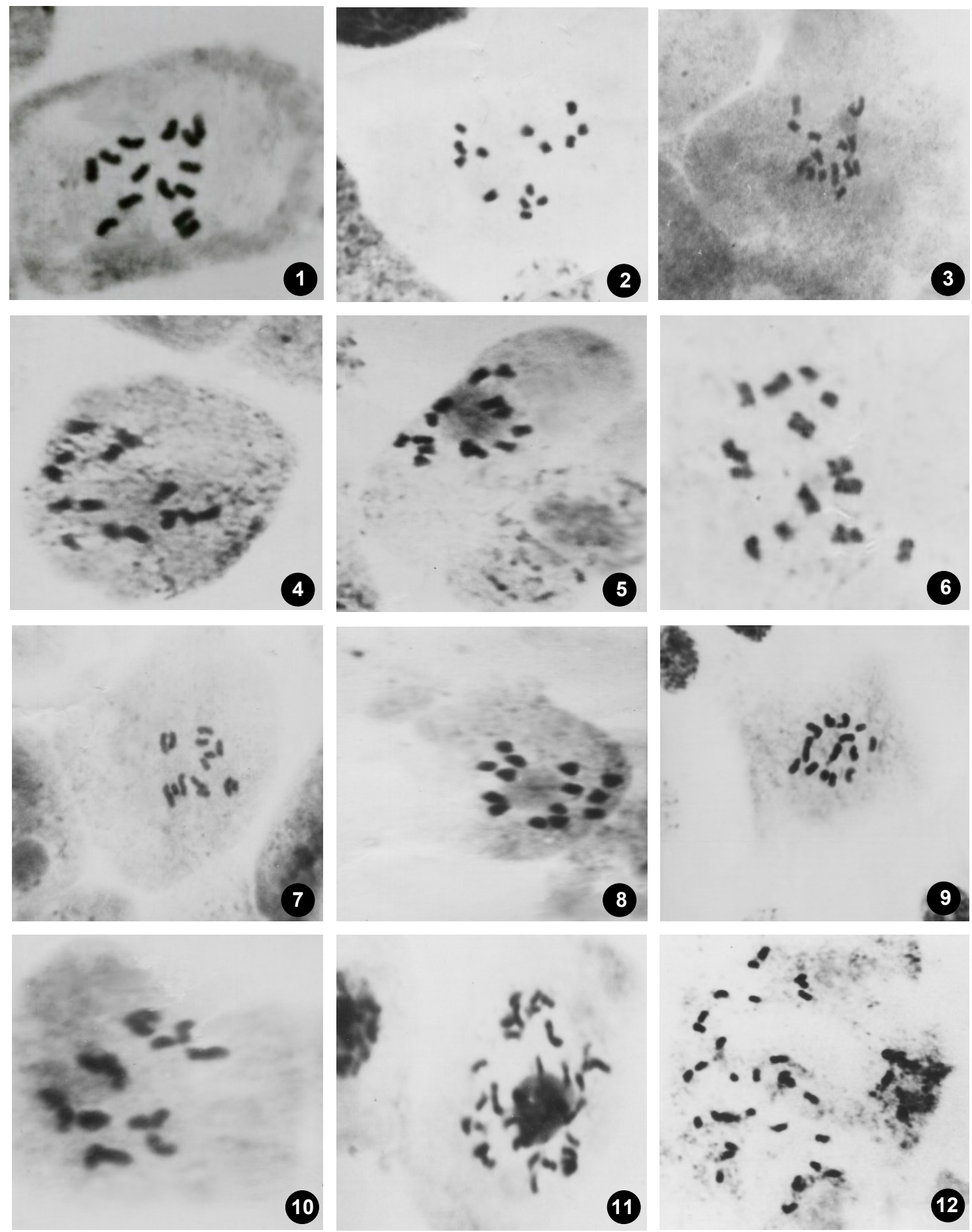
PLATE II

MITOTIC ABERRATIONS
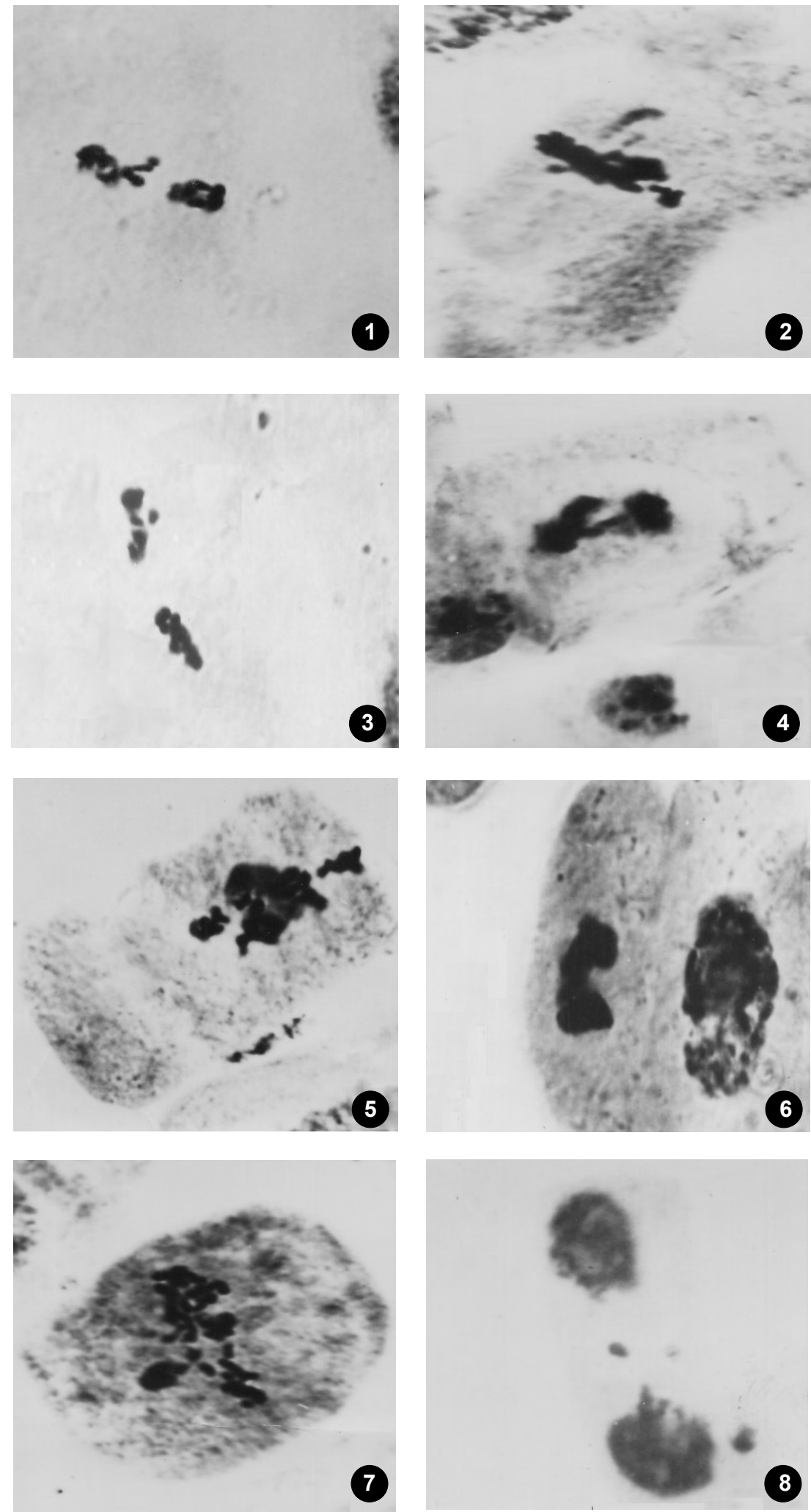
Table 1

\begin{tabular}{|c|c|c|c|c|c|c|c|c|c|c|}
\hline 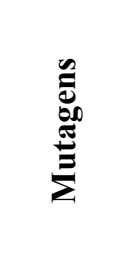 & 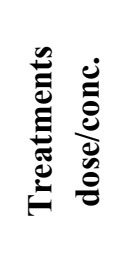 & 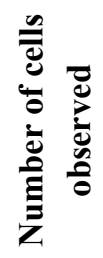 & 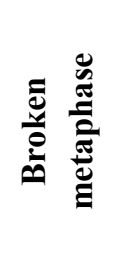 & 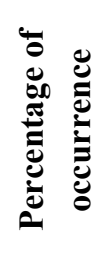 & 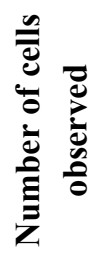 & 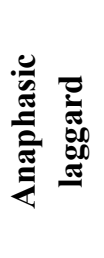 & 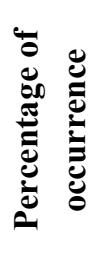 & 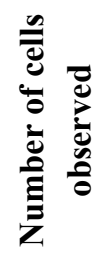 & 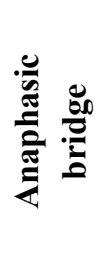 & 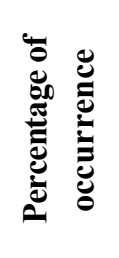 \\
\hline \multirow{4}{*}{$\begin{array}{c}\text { Gamma } \\
\text { Rays }\end{array}$} & Control & 86 & - & - & 93 & - & - & 102 & - & - \\
\hline & $60 \mathrm{kR}$ & 98 & 4 & 4.08 & 84 & 3 & 3.571 & 98 & 1 & 1.020 \\
\hline & $80 \mathrm{kR}$ & 120 & 7 & 5.833 & 102 & 6 & 5.882 & 115 & 4 & 3.478 \\
\hline & $100 \mathrm{kR}$ & 144 & 11 & 7.638 & 116 & 8 & 6.896 & 120 & 7 & 5.833 \\
\hline \multirow{4}{*}{ EMS } & Control & 81 & - & - & 76 & - & - & 96 & - & - \\
\hline & $0.4 \%$ & 89 & 2 & 2.247 & 89 & 2 & 2.247 & 112 & 3 & 2.678 \\
\hline & $0.6 \%$ & 112 & 4 & 3.571 & 108 & 4 & 3.703 & 109 & 5 & 4.587 \\
\hline & $0.8 \%$ & 142 & 7 & 4.929 & 128 & 7 & 5.468 & 130 & 8 & 6.153 \\
\hline \multirow{4}{*}{ SA } & Control & 92 & - & - & 84 & - & - & 112 & - & - \\
\hline & $0.02 \%$ & 110 & 3 & 2.727 & 101 & 4 & 3.960 & 116 & 4 & 3.448 \\
\hline & $0.03 \%$ & 137 & 5 & 3.649 & 124 & 6 & 4.838 & 120 & 7 & 5.833 \\
\hline & $0.04 \%$ & 125 & 8 & 6.400 & 120 & 7 & 5.833 & 132 & 9 & 6.818 \\
\hline \multirow{4}{*}{$\mathrm{COH}$} & Control & 99 & - & - & 101 & - & - & 110 & - & - \\
\hline & $0.12 \%$ & 148 & 11 & 7.432 & 126 & 5 & 3.968 & 115 & 6 & 5.217 \\
\hline & $0.14 \%$ & 156 & 13 & 8.333 & 148 & 9 & 6.081 & 125 & 11 & 8.800 \\
\hline & $0.16 \%$ & 128 & 16 & 12.500 & 124 & 10 & 8.064 & 136 & 15 & 11.029 \\
\hline
\end{tabular}

\section{CONCLUSIONS}

It is clear from the table that the more dosage level, the higher is the percentage of mitotic aberrations in gamma radiation, EMS, sodium azide and colchicine treated plants. Along with broken metaphases, anaphasic laggards and bridges, other types of abnormalities like clumping up of chromosomes, unequal anaphase, precacious movements of chromosomes during metaphases have been also rarely observed in all the plants treated with mutagenic agents and colchicine. It is clearly understood that the mitotic aberrations are more in colchicine treated plants than the plants treated with gamma rays, EMS and sodium azide. 


\section{Reference}

[1] Anonymous (2003). Agriculture in Pakistan statistic year book, federal bureau of statistics. Economic affair and statistics division, Government of Pakistan.

[2] Asthana A. N., Indian Agric. Sci. 68(8) (1998) 448-452.

[3] Baudoin J., A. Maquet, Phaseolus. Biotechnol. Agron. Soc. Environ. 4 (1991) 220-224.

[4] FAO (1970). Manual of mutation breeding. Tech. Rep. Ser. 119, IAEA, Vienna.

[5] Marimuthu K.M., M.K. Subramaniam, Curr. Sci. 29 (1960) 482-493.

[6] Mandal S., R.K. Mandal, Curr. Sci. 79 (2000) 576-589.

[7] Rangaswamy Ayyangar G.N., N. Krishnaswamy, Indian J. Agric. Sci. 3 (1933) 934-935.

[8] Venkatesan M. (1997). Studies on genetic divergence in cowpea. M.Sc. (Ag.) Thesis, Annamalai University, Annamalainagar. 